Submitted 22 $2^{\text {nd }}$ February 2021

Accepted $30^{\text {th }}$ June 2021

\title{
BALI TRAVEL PACKAGE ADVERTISEMENTS: THE ANALYSIS OF VERBAL AND VISUAL SIGNS
}

\author{
Ni Luh Gede Elsa Wiyanti ${ }^{1}$, Desak Putu Eka Pratiwi ${ }^{2}$, I Dewa Ayu Devi Maharani \\ Santika ${ }^{3}$ \\ Mahasaraswati Denpasar University, Indonesia ${ }^{1,2,3}$ \\ Elsawiyanti1234@gmail.com, desak.eka.pratiwi@gmail.com, \\ devimaharani17@gmail.com
}

\begin{abstract}
Advertisement is "an announcement or news online, or in a newspaper, on television, or on a poster about something such as a product, event, or job to persuade and encourage people to be interested in the goods or services offered". Verbal and nonverbal are communication tools that humans use to interact, whether it's through messages, sounds, pictures, and gestures. . This study aims to analysed the verbal and non-verbal signs used in the travel advertisements and to find out the meaning of those signs. Travel advertisements aim to promote tourist attractions or destinations to tourists who are going to make a trip in Bali. The data were taken from several travel websites. The data were collected by observation method and then analysed by descriptive qualitative method. The analysis started by analysing the verbal and non-verbal sign based on the theory of semiotic by Saussure (1893). The analysis of the meaning of the verbal and non-verbal signs was done by using theory of meaning proposed by Barthes (1977). And the analysis of colors was done by using the theory of color term proposed by Wierzbicka (1996). The result of the research shows that travel advertisements provide information for readers or tourists who are going to travel in Bali about interesting places to visit, such as romantic spots for dinner or honeymoon and natural view for the ones who love nature and adventure. The colors displayed in the advertisement express the atmosphere that will be obtained by readers or tourists. The advertisements promote Bali as wonderful places to visit and travel package offers which interesting and affordable.
\end{abstract}

Keywords: semiotic, verbal sign, nonverbal sign, travel advertisement

\section{INTRODUCTION}

Communication is a process of creating and using information to connect with environment and other people. In general, communication is done verbally which can be understood by both parties. If there are no verbal signs that both of them can understand, communication can still be done by using body movements or showing certain attitudes, for example smiling, shaking their heads, shrugging their shoulders, and by displaying certain pictures or symbols, this way is called as nonverbal communication. Verbal and nonverbal signs play a crucial role in communication.

Advertisement is also one of communication tools which employ verbal and 
nonverbal signs to deliver particular messages. Verbal signs are communication tools which using words or speech to exchange information or messages. Meanwhile, nonverbal signs refer to signals transmitted through facial expressions, posture, gestures, eye contact, body language, pictures, and signs.

Semiotic is the study of signs and symbols in particular to communicate thing in spoken and unspoken. It is a philosophical theory concern with understanding how people used signs and symbols in meaning-making. Sign is a composition of signifier and signified. Signifier is the material aspect of language. It refers to what we say or hear and what we write or read. And signified is the concept it represents.

Advertisements contain notification to the public with an objective to influence the readers to do what they want. Advertising is not limited to products, but also information, invitations, or calls to do something. Advertisement can be a communication tool, because advertisement in business is a type of communication that persuades and encourages people to take a particular action.

One example of a common advertisement is a travel advertisement in the form of a poster published by several travel companies in Indonesia. The advertisements which used in this study is a form general advertisement designed to provide information about a product or service that will be sold to the public, especially about holiday package in Bali. The language contained in the travel advertisement aims to attract the attention of readers to be interested in the advertisement and take particular action. This study aims to analyse verbal and non-verbal signs used in travel advertisements and discovering their meanings as well. Its very important to know about verbal and non verbal sign in advertisment because advertiser and consumer are not in visual contact, they communicate through the channel which in this case is an advertisement, in advertisement language and sign play an important role to convey commercial message to the consumers to make them interested in. It is mostly associated with advertising is interactional because it is used to express, maintain and terminate contact between the advertiser and the consumer. And in this study the researcher tried to decipher what messages were being conveyed in travel advertisement and how to find out the verbal and non-verbal signs used in travel adverstisement to analyze them in semiotic theory. By identifying verbal and nonverbal signs, it can help people to understand the meaning or message of these signs appropriately and avoid misunderstanding.

\section{METHODOLOGY}

The data of this study were taken from three travel website, such as: Candle Light Dinner Jimbaran (Kiu Tour), 6 Days in Bali Indonesia Itinerary (Morry Travel), and Honeymoon in Paradise (Bali Star Island). This study used observation method in collecting the data which involving the following steps. First, finding travel advertisements from the websites, downloading the advertisements, note taking and classifying verbal and non-verbal signs found in the advertisements. Meanwhile qualitative method was used to analyze the meaning of verbal and nonverbal signs using theory of semiotic proposed by Saussure (1983) the theory study about sign and symbol, supported by other relevant theories proposed by Barthes (1977) this theory study about meaning, in barthes theory develop into 2 levels 
including denotative and connotative meaning and Wierzbicka (1996) in this theory study about color term. The data then presented in formal and informal method.

\section{RESULT AND DISCUSSION}

This section describes the meaning of verbal and nonverbal signs, which found in travel advertisements.

\subsection{Advertisement 1: Candle Light Dinner Jimbaran}

\subsubsection{The Analysis of Verbal Signs in Candle Light Dinner Jimbaran Advertisement}

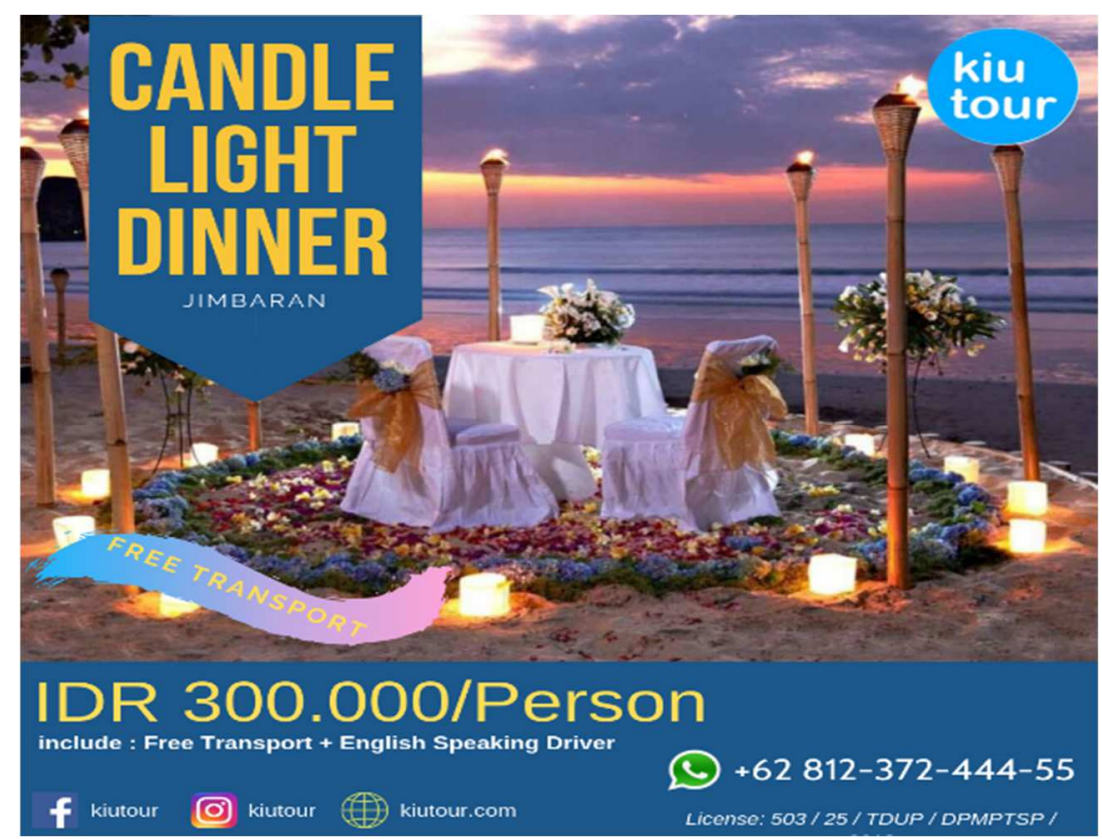

Figure 1. Candle Light Dinner Jimbaran

Source: Kiu Tour (http://kiutour.com/car/north-bali-tour-2019/)

The first verbal sign is "Candle light dinner Jimbaran". It means that the advertisement promotes dinner for the couple which is lit by candles to create a romantic atmosphere. A candle light dinner usually happens in a quite expensive restaurant, decorated appropriately with mindful table set up. Jimbaran is a great location for candle light dinner since it has many places with a romantic atmosphere. The statement has a denotative meaning because candle light dinner actually means a romantic dinner with candle decoration in Jimbaran.

The second verbal sign is "Free Transport means this travel package includes free transportation service both for pick up and drop off. So, you do not need to think about the transportation that will be used to go to your destination. This statement has denotative meaning because it explicitly tells the reader that the package includes additional facilities which is free transportation.

The third verbal sign are "IDR 300.000/person, include: free transport + 
English driver, +62 812-372-444-55". The statement gives information about the price of the package which included free transportation and English-speaking drivers. In addition, it also gives further information about the contact person and the price. The statement simply has denotative meaning because it represents the real meaning and no hidden meaning.

The fourth verbal signs are "Facebook: Kiutour, Instagram: Kiutour, website: Kiutour.com". It means the guest can see more detailed information about the travel package from the social media. People also can see the reviews and comments from others who had used the travel service.

\subsubsection{The Analysis of Nonverbal Signs in Candle Light Dinner Jimbaran Advertisement}

The first picture is a private table for two with romantic ambience, including bouquet of flowers, nice decoration and table cloth, blossoms and candles for a special atmosphere. Moreover, there are flowers spread over the sand and surrounded by beautiful torches. Perfect for an anniversary, a proposal in Bali, birthday or other important events. The table is set attractively in order to give special vibe for the couple. This picture convinces people to take a decision to buy the package.

The second picture is the beach. In the advertisement, the beach has an important role because the beach has a romantic impression. For some couples, having a romantic candle light dinner would create the best night to remember. Especially, if you could do that at the beachfront, under the starry night, and on the exotic island of Bali. Jimbaran beach is one of the most beautiful beaches of the world where honeymoon couples can have fresh sea food. The couples can sit together on the beach with their chair and table and their toes relaxing into the amazing sand of the beach. This place is also famous for its amazing sunset that will make your romantic dinner absolutely perfect. Most of Bali honeymoon packages include this site.

Third picture is the sunset. Sunset is identical with romance. Many people hunt for sunset to get a romantic moment. The sky is in dark orange and grey colors. Orange is associated with meaning of joy, warmth, heat, enthusiasm, encouragement, sexuality, freedom, etc. Orange promotes a sense of general wellness and emotional energy that should be shared. Orange will help a person recover from disappointments, a wounded heart, or a blow to one's pride. Meanwhile grey represents neutrality and balance. Its color meaning likely comes from being the shade between black and white. Colors play important role in how brand is perceived. Colors can be used to help build a strong, relatable brand. 


\subsection{Advertisement 2: 6 Days in Bali Indonesia Itinerary}

\subsubsection{The Analysis of Verbal Signs in 6 Days in Bali Indonesia Itinerary Advertisement}

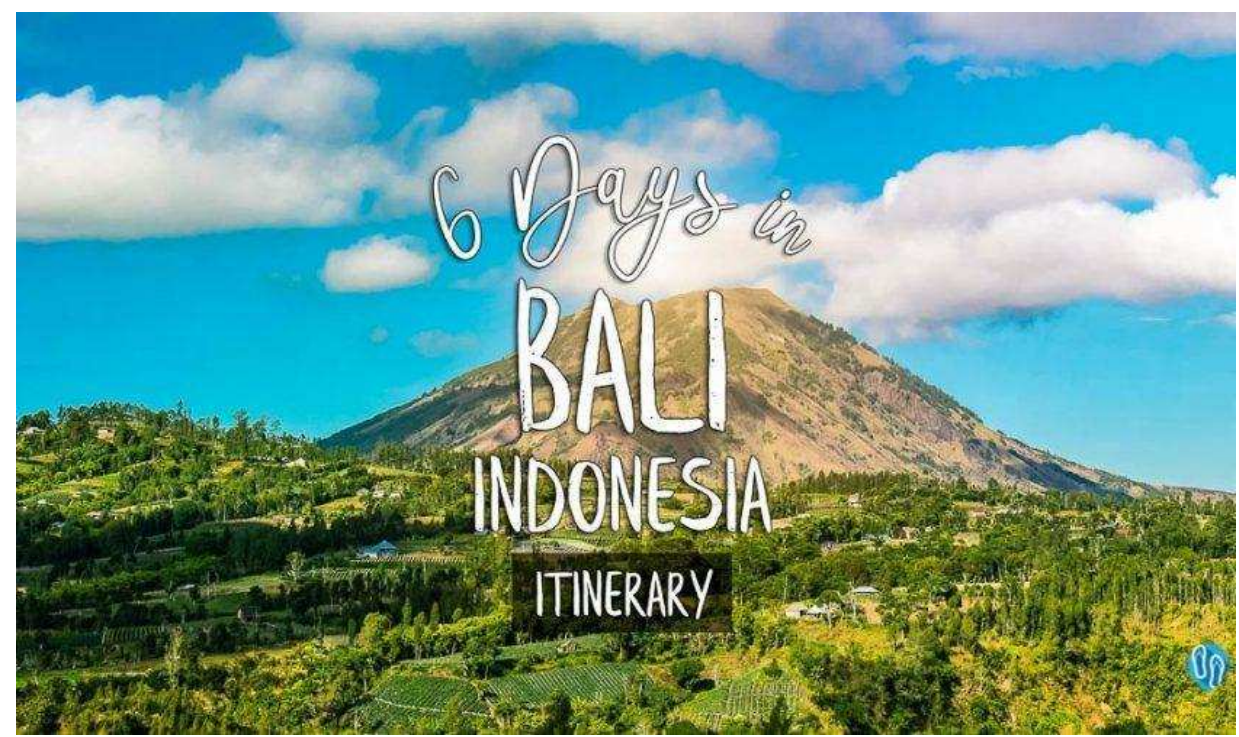

Figure 2. 6 Days in Bali Indonesia Itinerary

Source: Morry Travel https://www.morrytravels.com/about-morry-travels/

The verbal sign in this advertisement is " 6 days in Bali Indonesia itinerary". Itinerary is a detailed planning schedule for a trip to be carried out with an estimated budget to be issued and a tour that has been systematically arranged to provide comfort and satisfaction for tourists. The statement has denotative meaning because the statement explains clearly about the travel package which is six days in Bali. Most travelers come to Bali for a few weeks, backpacking through the hidden gems of Bali and relaxing with the Bali vibes. However, not everyone can afford to take a long vacation. Some people might just have 5 days to travel, some might have 10 days. So that 6 days Bali itinerary is an interesting offer for tourists. With affordable budget they can visit from Balinese temples to waterfall and beaches. All in one package which bring you to the paradise.

There are many benefits to using a travel agent, from saving time and money to unlocking special perks and benefits. Today, agents are more popular than ever and playing a key role in the continued growth of the travel and tourism industry. Travel agents take care of every aspect of your trip, from your flights and hotel to ground transportation and excursions. Therefore, clients can be organized without having to stress over the planning process. Moreover, agents have access to the best deals and the expertise to get you more for your money. Agents can craft your ideal itinerary and personalize your experience by putting their knowledge, contacts and own experiences to work. They will know what you can expect ahead of time and can make special requests on your behalf. 


\subsubsection{The Analysis Nonverbal Signs in 6 Days in Bali Indonesia Itinerary Advertisement}

The advertisement uses the picture of beautiful mountain in the poster representing Bali as a very beautiful island with wonderful view. Blue sky with white cloud, aims to show if the place has a good weather with the good atmosphere. According to theory of color terms proposed by Wierzbicka (1996: 310), blue color is a natural color that describes health, gentleness, power, and seriousness while white color means purity and goodness. So, the clear blue sky with white clouds and the cool atmosphere in the mountains aims to show if the place has positive energy for the visitor. The picture has connotative meaning because the image shows if the place has good weather for visitor and suitable for relieving fatigue.

The picture of mountain shows that Bali is blessed with many natural wonders. The island is often primarily associated with beaches. However, there is so much more to discover. Tourists can explore the high grounds of Bali as the island has several volcanic mountains, mostly located in the north. To the Balinese mountains are mystical and significant to Bali's Hindu religion. They are revered as they generate rich soil, create landforms and give life to the island. There are major temples located in the mountain areas that attract many visitors, some come for religious purposes, but others come for the challenge and the breath-taking views from the top-overlooking the whole island. The picture of the mountain is in light brown color. According to theory of color terms proposed by Wierzbicka (1996:327), the color brown means strong and reliable and symbolizes a foundation and life force. There is also black color on the picture of the mountain which is the remnants of sand from the erupting mountain, which makes the scene look natural.

The picture of green beautiful view in the posters shows that Bali is packed with great natural attraction that tourists might not able to discover in just a single visit. Bali's great attractions are a fine blend of natural wonders, ranging from highlands with active volcanoes to flowing waterfalls, peaceful lakes and forested mountains. Set in harmony with the environment. According to theory of color terms proposed by Wierzbicka (1996:307), green color represents fertility, growth and natural. The green color of the image comes from the colors of the leaves, trees and other green plants. The advertisement is designed to attract tourists to visit the island. 


\subsection{Advertisement 3: Honeymoon in Paradise}

\subsubsection{The Analysis of Verbal Signs in Honeymoon in Paradise Advertisement}

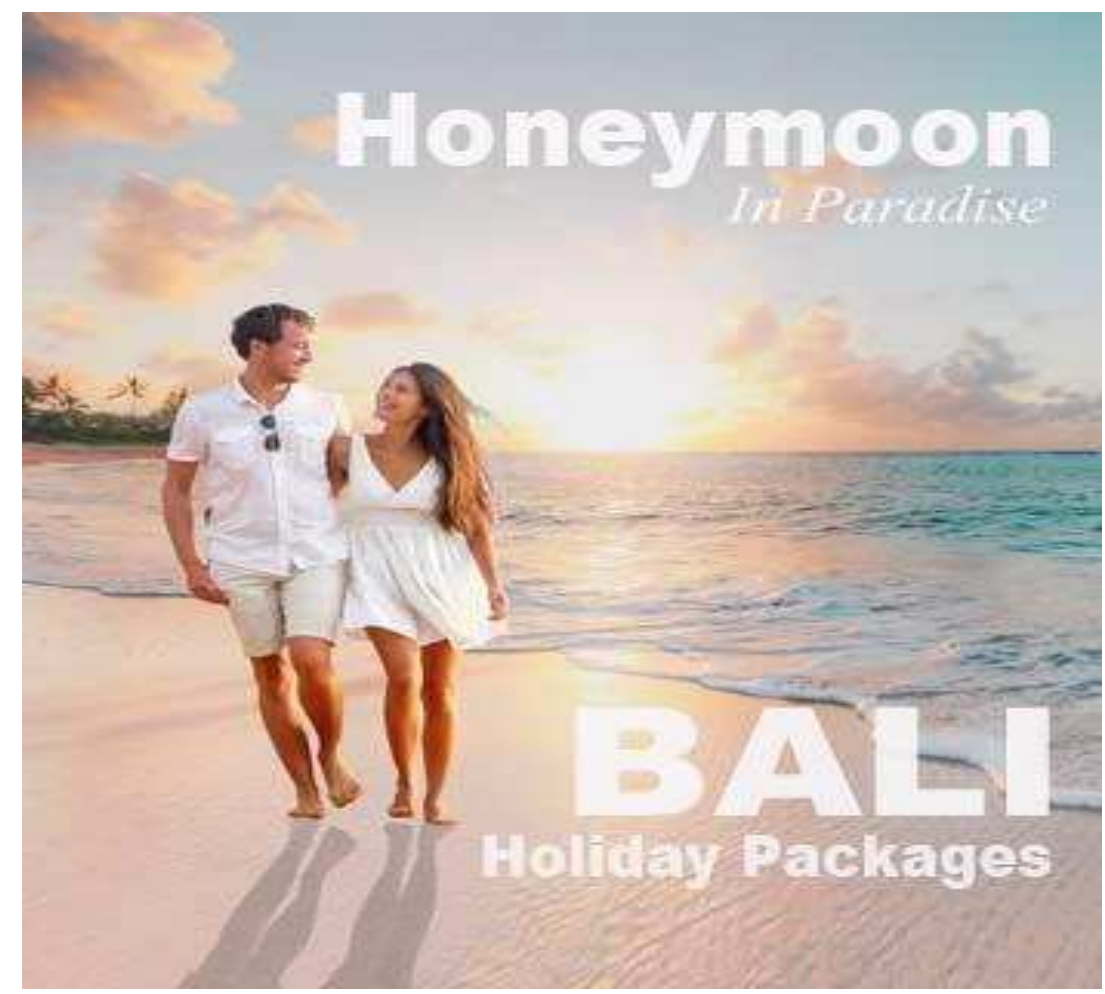

Figure 3. Honeymoon in Paradise

Source: Bali star Island, PT. Bewish International Tour https://balistarisland.com/company-about/

Couples seeking for the most romantic getaways have been travelling to Bali for honeymoon. The first statement in the advertisement is "Honeymoon in Paradise". Honeymoon is a trip made by a newly married couple. Honeymoon is often celebrated in romantic and private places with special requests, such as rooms decorated with flowers or special food and drinks. Paradise has similar meaning with heaven which is the final realm of life which is reserved for good people. It is abstract concept which represents a very beautiful place. Meanwhile paradise in this case refers to a paradise on earth, Bali island, since Bali has many beautiful places which make people feel like in heaven. So, honeymoon in paradise is a trip taken by a newly married couple in the island of Bali or the island of paradise.

The second statement is "Bali holiday packages". Holiday packages are usually offered by travel companies at lower price. If you bought a travel package everything will be organized by the travel agent, such as hotels, food, transportation, and tickets for other tourist attractions. So that taking a travel package is much easier than taking care of the trip by yourself. To travel around the world is one the best things to do. But travelling with a life partner becomes even more beautiful. Bali is one of the best places for honeymoon holidays. It is not only a romantic place but a scenic place as well where tourists can do some unusual and cool things. 


\subsubsection{The Analysis of Nonverbal Signs in Honeymoon in Paradise Advertisement}

The first nonverbal sign is the photo of a couple who are the model of the honeymoon package advertisement. They both wear white outfits. White, an inherently positive color, is associated with purity, virginity, innocence, light, goodness, heaven, faith, beginnings, sincerity, protection, softness, and perfection. It fits the message of the advertisement which presented for newlywed who start a new beginning in their life chapter with pure love and sincerity. The picture shows how happy they are, spending time and creating a life time memory in Bali. This image is used to persuade and invite people to spend their honeymoon in Bali.

The sky is yellowish in the afternoon because of the sunset. Bali island is well known for the sunset view which is normally seen from the beach shoreline. Beaches in Bali are very well-known to travellers at the best place to see a sunset on a white sand beach, which is preferable for a honeymoon couple. The sunset makes the sky dramatically turns yellowish. According to theory of color terms proposed by Wierzbicka (1996: 316), yellow represents feelings of joy. Yellow, the color of sunshine, hope, and happiness. Yellow stands for freshness, happiness, positivity, clarity, energy, optimism and enlightenment.

Another nonverbal sign in this advertisement is the picture of beach. Beach is one of the most interesting places in Bali island, especially the white sand beach. The picture shows a beautiful blue beach with white sand where the newly wed pose happily. According to theory of color terms proposed by Wierzbicka (1996: 310 ), blue represents a feeling of calm and white represents kindness and purity. Blue represents both the sky and the sea, and is associated with open spaces, freedom, intuition, imagination, inspiration, and sensitivity. Blue also represents meanings of depth, trust, loyalty, sincerity, wisdom and stability. The color blue has positive effects on the mind and the body. As the color of the spirit, it invokes rest and can cause the body to produce chemicals that are calming and exude feelings of tranquillity. So, the atmosphere of blue sea water and white sand in the picture has a positive meaning and is able to convince people to come to this beautiful paradise on earth.

\section{CONCLUSION}

The results of this study found that all of three travel advertisements poster published by three travel companies composed of verbal and non-verbal signs. The types of verbal signs found in those three travel advertisements were phrases, clauses, and sentences that enable to tell the advertiser's ideas and feelings to others. Verbal signs are used as a media to deliver messages in the form of words to the public. The non-verbal signs in those poster advertisements classified into three: pictures, models, and scenery as background.This study also concerned with the meanings that were described through the verbal and non-verbal signs in three travel advertisements. The denotative meaning is the true meaning or does not contain additional feelings. The connotative meaning is an indirect meaning that has the aim of dismantling hidden meanings. 


\section{REFERENCES}

Barthes, R. 1977. Elements of Semiology. (A. L. Smith, Trans.) New York: HILL and Wang.

Cambridge, D. 2020. Definition of Poster. Retrieved from https://dictionary.cambridge.org/dictionary/english/poster

Cambridge, D. 2020. Definition of travel. Retrieved from https://dictionary.cambridge.org/dictionary/english/travel

Kusters, A. 2020. The Tipping Point: On the Use of Signs from American Sign Language in International Sign. Language \& Communication, 75, 51-68. doi: https://doi.org/10.1016/j.langcom.2020.06.004

Marina Lourenção, J. d. 2020. Destination Advertisement Semiotic Signs: Analysing Tourists' Visual Attention and Perceived ad Effectiveness. Annals of Tourism Research, 84. doi: https://doi.org/10.1016/j.annals.2020.103001

Regina Kaplan-Rakowski, B. L.-P. 2019. The Impact of Verbal and Nonverbal Auditory Resources on Explicit Foreign Language Vocabulary learning. System, 85. doi: https://doi.org/10.1016/j.system.2019.102114

Saussure, F. d. 1893. In H. S. Perry Meisel (Ed.), Course in General Linguistic (W. Baskin, Trans.). New York: Columbia University Press.

Wierzbicka, A. 1996. SEMANTIC: Primes and Universal. New York: Oxford University Press. 